\title{
Brostacillin Hydrochloride
}

National Cancer Institute

\section{Source}

National Cancer Institute. Brostacillin Hydrochloride. NCI Thesaurus. Code C128040.

The hydrochloride salt form of brostacillin, a synthetic, alpha-bromoacrylic, secondgeneration minor groove binder (MGB), related to distamycin A, with potential antineoplastic activity. Brostallicin binds to DNA minor groove DNA, after having formed a highly reactive glutathione (GSH)-brostallicin complex in the presence of the enzyme glutathione S-transferase (GST), which is overexpressed in cancer cells; DNA replication and cell division are inhibited, resulting in tumor cell death. Compared to typical MGBs, this agent appears to bind covalently to DNA in a different manner and its activity does not depend on a functional DNA mismatch repair (MMR) mechanism. Accordingly, brostallicin may be effective against MMR-defective tumors that are refractory to various anticancer agents. 